\title{
Indigenous Knowledge and Long-term Ecological Change: Detection, Interpretation, and Responses to Changing Ecological Conditions in Pacific Island Communities
}

\author{
Matthew Lauer · Shankar Aswani
}

Received: 28 October 2009/Accepted: 1 March 2010/Published online: 25 March 2010

(C) The Author(s) 2010. This article is published with open access at Springerlink.com

\begin{abstract}
When local resource users detect, understand, and respond to environmental change they can more effectively manage environmental resources. This article assesses these abilities among artisanal fishers in Roviana Lagoon, Solomon Islands. In a comparison of two villages, it documents local resource users' abilities to monitor longterm ecological change occurring to seagrass meadows near their communities, their understandings of the drivers of change, and their conceptualizations of seagrass ecology. Local observations of ecological change are compared with historical aerial photography and IKONOS satellite images that show 56 years of actual changes in seagrass meadows from 1947 to 2003 . Results suggest that villagers detect long-term changes in the spatial cover of rapidly expanding seagrass meadows. However, for seagrass meadows that showed no long-term expansion or contraction in spatial cover over one-third of respondents incorrectly assumed changes had occurred. Examples from a community-based management initiative designed around indigenous ecological knowledge and customary sea tenure governance show how local observations of ecological change shape marine resource use and practices which, in turn, can increase the management adaptability of indigenous or hybrid governance systems.
\end{abstract}

M. Lauer ( $\square)$

Department of Anthropology, San Diego State University, 5500 Campanile Drive, San Diego, CA 92182-6040, USA e-mail: mlauer@mail.sdsu.edu

S. Aswani

Department of Anthropology and IGP Marine Science,

University of California-Santa Barbara, Santa Barbara, CA, USA
Keywords Environmental change $\cdot$ Indigenous ecological knowledge $\cdot$ Remote sensing · Marine historical ecology $\cdot$ Seagrass $\cdot$ Solomon Islands

\section{Introduction}

Human impact on the biosphere has reached unprecedented levels. Declining biodiversity, melting glaciers and ice sheets, and impending collapse of entire ecosystems (Steffen 2004; IPCC 2007) paint an unsettling picture of how contemporary industrial societies are undermining the very ecosystems upon which humans depend for services and support. Marine ecosystems, in particular, are under considerable threat (Jackson and others 2001; Worm and others 2009). These troubling trends are motivating scholars and researchers in the human and natural sciences to search for alternative resource management frameworks that sustain rather than undermine ecological systems (Gunderson and Pritchard 2002; Berkes and others 2003; Olsson and others 2004; Hughes and others 2005; Liu and others 2007). This effort toward sustainability has led to increasing interest in certain traditional societies such as arctic hunting-gathering peoples (Berkes 1998), pastoralists (Niamer-Fuller 1998), and some "neo-traditional" groups (e.g., Begossi 1998), who have been shown to engage in resource management practices that are appropriately adapted to the local ecology and can maintain biodiversity. Pacific Island fisherfolk, in particular, have received much scholarly attention because of their customary management practices that under certain circumstances are conducive to sustainable marine resource use (Johannes 1978; Aswani 2005; Cinner and others 2005a; Drew 2005). It is important to note, however, that in some cases indigenous practices are ecologically damaging 
(Krech 1999; Hames 2007; Erlandson and Rick 2009) and would serve as poor guides to resource regulation.

Studies of traditional resource management practices have shown how local resource users have knowledge that can be useful for ecological research and environmental management decisions. This has led to focus on "hybrid" research in which scientific and indigenous or local knowledge are integrated (Murdoch 1994; Stoffle and others 1994; Huntington 2000; McClanahan and others 2006; Aswani and others 2007). Particularly exciting are collaborative projects that draw on local knowledge to assess the impacts of climate change (Berner and others 2005; Crate 2008). Co-management frameworks, where local practitioners, environmental managers, and policy makers collaborate in the design, implementation, and enforcement of managing ecosystems, have also become increasingly important (Pinkerton 1989; Sillitoe 1998; Folke and others 2005).

The importance of local knowledge for resource management has also been propelled by current adaptivemanagement approaches (Holling 1978; Walters 1986; Hughes and others 2005), which argues that sustainable resource management is best achieved when viewed as an adaptive process where the feedbacks between people and ecosystems shape management policies. In contrast to conventional frameworks, adaptive management assumes that ecosystems are unpredictable and that knowledge about them is incomplete. Many of these same principles of adaptive management form the core of customary governance systems. These traditional systems, as well as other local-level management frameworks, have been shown to rely on resource users' knowledge and expertise, which in effect amount to an adaptive management approach (Berkes and others 2000; Dietz and others 2003).

However, effective ecosystem management and customary governance practices rely on the ability of local resource users to detect, understand, interpret, and respond to ecological change. Yet, few studies have empirically tested the change-detection abilities of indigenous people because adequate historical information on ecological change tends to be scarce or unreliable. In addition, the bulk of indigenous knowledge studies have focused on knowledge of structures such as taxonomy or species distribution rather on knowledge pertaining to the functional characteristics of species and how they interrelate to overall ecosystem dynamics through time.

In this paper we evaluate (1) the abilities of fishers in Roviana Lagoon, Solomon Islands to monitor long-term ecological change occurring to seagrass meadows near their communities; and (2) their understandings of the dynamic drivers of change. We used historical aerial photography and IKONOS satellite images to detect actual vegetation change in seagrass meadows over a 56-year period from 1947 to 2003. Then, we cross-referenced this information with people's perceptions of environmental change in seagrass meadow coverage around their communities to investigate how local people perceive ecological change, what they think is driving it, and how they respond to it. Finally, we discuss how ecological knowledge about long-term environmental change occurring to the lagoon ecosystem can feedback into resource-management strategies and an ongoing community-based conservation program.

\section{Study Site}

The Solomons are the third largest archipelago in the South Pacific and comprise over 900 islands, six of which constitute the bulk of the land area. Along the southern coast of one of the main islands, New Georgia, is Roviana Lagoon, a 42-km-long system of protected bays that are known as some of the richest and most diverse marine ecosystems in the world (Green and others 2006). Reaching $5 \mathrm{~km}$ in width, the sizeable inner lagoons consist of myriad pools, coral reefs, intertidal flats, and passages. Large portions of the lagoon are shallow $(<20 \mathrm{~m})$ and contain a multitude of marine habitats, including seagrass meadows, mangroves, freshwater swamps, river estuaries, sand channels, shallow coral reefs, silt-laden embayments, and reef drops. New Georgia has steep, rugged terrain of volcanic origin with an eroded crater at its center. The interior part of the mainland, although populated in the past, is now uninhabited and consists of thick montane and lowland rainforest. In contrast, the barrier islands and coastal strip have undergone centuries of forest clearing and swidden agriculture, resulting in a patchwork of gardens, fallow plots, scrub lands, and stands of regenerating and mature forest (Walter and Sheppard 2000).

Roviana Lagoon is home to approximately 7,000 inhabitants who share a common linguistic and cultural heritage (Fig. 1). Over half of the population resides in the more developed western edge of the lagoon in the communities of the Munda and Nusa Roviana areas. Residents of the central and eastern section of the lagoon are more isolated and live in villages ranging from 50 to 1,000 inhabitants that spread along the barrier islands and the coastal strip of the New Georgia mainland. These communities continue to rely on fishing and horticulture as their means of subsistence despite extensive social and cultural change over the past two centuries. Subsistence fishing dominates village life, and marine resources provide the bulk of the protein in the people's diet. Most households also engage intermittently with the cash economy and undertake commercial activities such as copra production, shell-diving, or the marketing of fish, shellfish, fruits, and vegetables. Logging operations have also proliferated over the last several decades and 

with Roviana Lagoon inset. The two outlined areas within the lagoon inset map indicate the specific research site locations
Fig. 1 The Solomon Islands

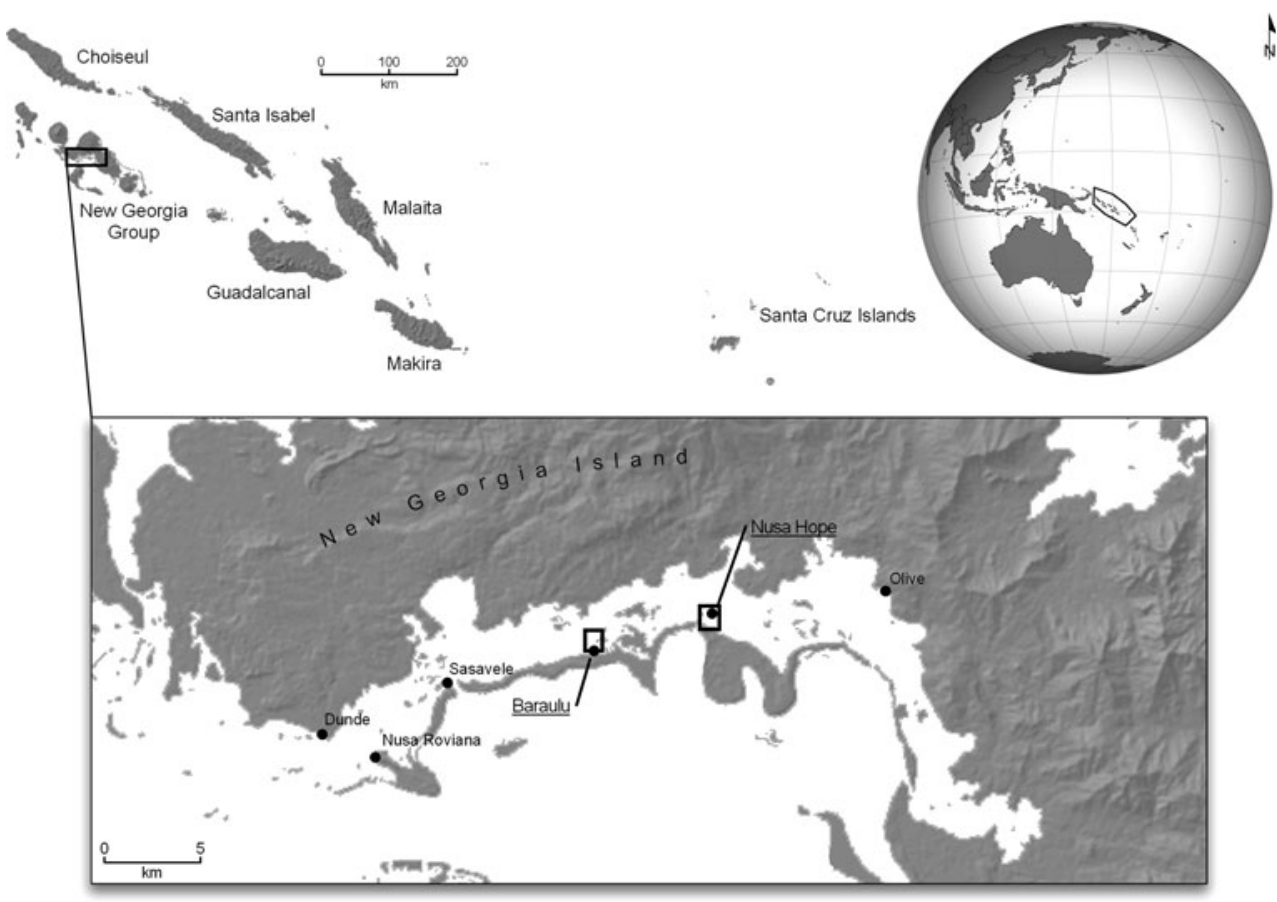

many local men now find seasonal employment as laborers in the timber industry, while women are hired as domestic workers.

Local community leaders in this region exercise governance and management over the use of and access to natural resources in the lagoons and the adjacent coastal areas within their respective customary land and sea estates. Despite this system of indigenous land and sea tenure, population growth and growing development pressures have begun to overwhelm local governance controls and undermine sustainable resource use. Increasingly, the lagoon ecology and the social and political stability of the region are under threat.

Many Roviana villagers have highly detailed knowledge of the surrounding marine environment and a sophisticated social-ecological habitat classification system. Seagrass meadows are know as kulikuliana and most Roviana villagers recognize and classify major marine habitats that often contain seagrasses including bolebole (tidal sand banks), holapana or sangava (lagoon passages), kopi (lagoon pools), nunusa (lagoon islands), sada ovuku (river mouths), sagauru (generic for reefs), and teqoteqo (reef drops), among others. Habitat classes are based on a combination of geomorphology, abiotic substrates, and benthic assemblages of plant and animal species, and they are embedded within the more general social-ecological domain know as poana or koqu (inner lagoon). Poana is one of the four major social-ecological domains identified by most Roviana informants. The other three include lamana (open sea), vuragare or toba (barrier islands and open-sea-facing

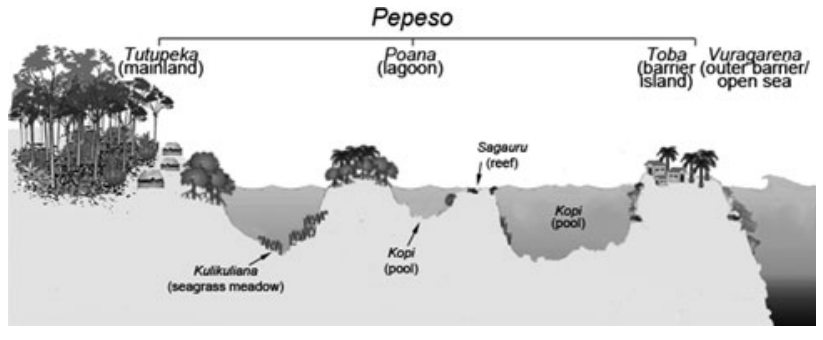

Fig. 2 Cross-section schematic of a generalized Roviana pepeso, showing local environmental classifications and their approximate English equivalents

inter-tidal zones and reef drops), and tutupeka (mainland) (see Aswani and Vaccaro 2008 for further discussion). All of these categories are organized around the highly significant concept of pepeso (Fig. 2). Although it literally translates as "soil" or "ground," pepeso is typically used as a broader land-sea concept that demarcates territorial estates and historical claims. As is the case elsewhere in the Pacific, Roviana land and sea ecological zones and processes are not ontologically separated but rather are components of an integrated whole. Pepeso signifies habitation, history, and land and sea territories, and it is the basic element in Roviana tenurial systems of ownership. Each pepeso consists of a named land and sea "estate" owned by a butubutu (kinbased group) and delineated by voloso (boundaries). The land-sea territory includes the open sea out to the midpoint in the channel separating New Georgia from Rendova Island as well as the barrier islands, passages, inner lagoons, and the New Georgia mainland. 
The seagrass meadows studied in this research are near the communities of Baraulu and Nusa Hope. The villages are located $5.5 \mathrm{~km}$ apart in the central part of the lagoon. With 450 and 750 permanent residents, respectively, Baraulu and Nusa Hope are densely clustered household groups that occupy barrier islands near narrow, 200-mwide lagoon passages. Baraulu village sits on a small, 200 by 250-m-wide peninsula that juts northward from the main barrier island. Nusa Hope includes seven settlements on both sides of the lagoon passage. The Baraulu and Nusa Hope seagrass meadows are similar in their substrate characteristics and species composition. They are predominately sub-tidal reef flats with narrow inter-tidal fringes consisting of mixtures of course carbonate sand, coral rubble, and silt. The dominant seagrass species include Enhalus acoroides and Thalassia hemprichii as well as smaller amounts of Halophila ovalis, Cymodocea rotundata, Cymodocea serrulata, and Halodule uninervis, among other species. Nusa Hope's seagrass meadows grow along the immediate eastern and southern shore of Nusa Hope Island and continue south along a tidal flat toward the northern shore of a large barrier island. Villagers of Nusa Hope are intimately familiar with this seagrass meadow and rely heavily on it for their daily subsistence needs. Baraulu's seagrass meadow is located approximately $700 \mathrm{~m}$ north of the village on an inter-tidal flat in the middle of a large reef system.

We chose to assess seagrass meadows because their spatial extent can be delineated with reasonable accuracy (particularly meadows composed of E. acoroides) using remote-sensing methods. Seagrass meadows are also of vital ecological function. They rank as some of the most productive ecosystems on earth, providing significant $\mathrm{CO}_{2}$ uptake and enhancing biodiversity (Larkum and others 2006). Despite their importance, seagrass ecosystems are now in dramatic decline in most parts of the world, with global seagrass losses estimated at 2-7\% year (Orth and others 2006; Duarte and Gattuso 2008; Waycott and others 2009). The declines are attributed to human activities such as deforestation, mangrove clearing, and other disturbances of terrestrial vegetation in coastal watersheds that result in increased terrigenous runoff and associated sediment discharge being transported down streams and rivers into coastal waters. These suspended sediments create turbidity that decreases water clarity and reduces the light available to seagrass, hindering its growth and development. The worldwide loss of seagrass poses a major threat to coastal ecosystems (Short and Wyllei-Echeverria 1996; Duarte 2002; Green and Short 2003; Short and others 2007; Waycott and others 2009) and yet they receive less attention than other coastal ecosystems such as coral reefs (Duarte and others 2008).

\section{Methods}

\section{Semi-structured Interviews}

Over a period of 6 weeks (July-August 2008) semi-structured interviews were conducted in Baraulu and Nusa Hope villages to assess local perceptions of ecological change. This work builds on almost two decades of ethnographic and human ecological research in the region. Face-to-face interviews were conducted with the heads of 35 households in Baraulu and 40 households in Nusa Hope. We selected an even number of male and female heads for a balanced representation. The interviews were conducted either in Solomon Islands Pijin or the Roviana language. During the household visits, the oldest man or woman available in a household was selected for the interview, which created a sample in which $64 \%$ of the respondents were older than 45 . In addition, we only interviewed those villagers who were born in the village and had spent most of their lives there. Each semi-structured interview took 20-30 min and involved a set of basic demographic questions (date of birth, gender, etc.), followed by a series of key discussion points about the seagrass surrounding the village. These standardized questions allowed for later comparison, but we also made sure that they were flexible and open-ended so that any important issues, perceptions, or ideas could be raised and discussed.

\section{Group Interviews}

We conducted two group interviews with locally acknowledged "experts" to complement the semi-structured interviews with household heads. Using a snowball sampling technique, we produced a list of names of individuals who villagers considered experts about the ecology surrounding their communities. Villagers tend to assess a person's ecological knowledge based on their fishing skill, an aptitude that is frequently discussed because the vast majority of households rely on fishing for daily sustenance. We conducted the group interviews in situ to maximize our informants' abilities to provide detailed and nuanced descriptions of seagrass ecology. This is a technique that we had used in the past to collect local ecological knowledge, which has been shown to provide more in-depth knowledge than standard, household interviews (Aswani and Lauer 2006; Lauer and Aswani 2008; 2009). The Baraulu interview was conducted in a boat, floating on top of the seagrass. The Nusa Hope interview was conducted wading through the seagrass meadows that grow along the shore immediately adjacent to the village. During these group interviews, questions and discussion were openended and focused on the ecology of the seagrass and any changes that had occurred over the informants' lifetimes. 


\section{Multi-temporal Analysis}

A 56-year (1947-2003) time series was assembled to detect long-term changes in the overall size of seagrass meadows around Baraulu and Nusa Hope (Figs. 3, 4). Historical aerial photographs of the Solomon Islands were acquired with the help of the Ministry of Lands, Housing, and Survey. We scanned four 9-in. by 9-in. black-and-white and color aerial photographs taken over Nusa Hope village on Oct-1947, May-1969, April-1979, and Oct-1991 (the only color photo). A similar set of aerial photographs taken over Baraulu Village on Oct-1947, May-1969, April-1979, and Feb-1983 were also scanned. These photographs varied in scale between 1:25,000 and 1:50,000 and were of relatively high quality. The 2003 image of the time series was acquired on February 8th by the IKONOS satellite. IKONOS is a high-resolution sensor that collects $174-\mathrm{km}^{2}$, scenes at 4-m multispectral and 1-m panchromatic resolution.

To geo-reference the aerial photographs and improve the accuracy of the IKONOS image, we collected ground control points from rooftops, WWII wreckage, and other suitable features that could be identified on the images and on the ground. At these sites, data were taken using two Geoexplorer XT GPS receivers (rover and base data). We performed differential correction on the GPS data using Pathfinder Office version 2.90; then we used ESRI ArcGIS 9.2 to geo-reference the image using the nearest-neighbor re-sampling method. With these images we created vector layers of the seagrass meadows using heads-up digitization. This is a process in which the outline of the object or habitat (in this case seagrass patches) is visually interpreted from the images and then digitized to create polygons. We identified seagrass meadows on the IKONOS imagery
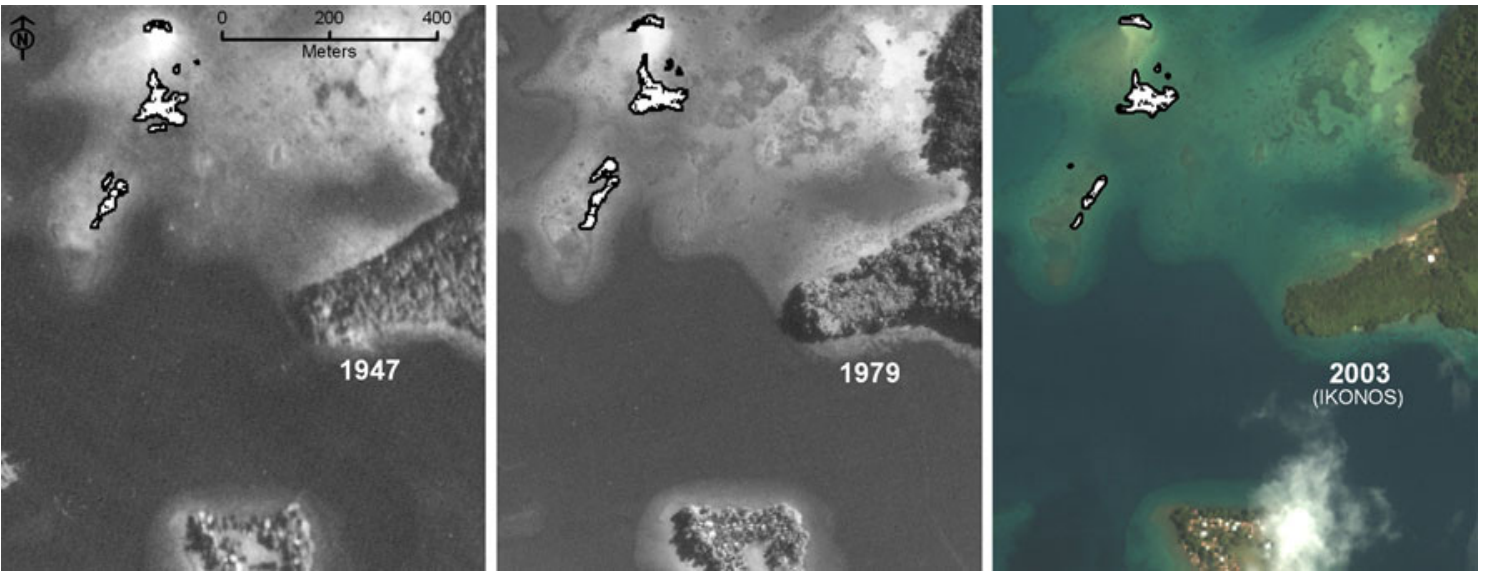

Fig, 3 Air photographs and satellite image with delineated areas indicating the size of seagrass meadows at Baraulu Village in 1947, 1979, and 2003
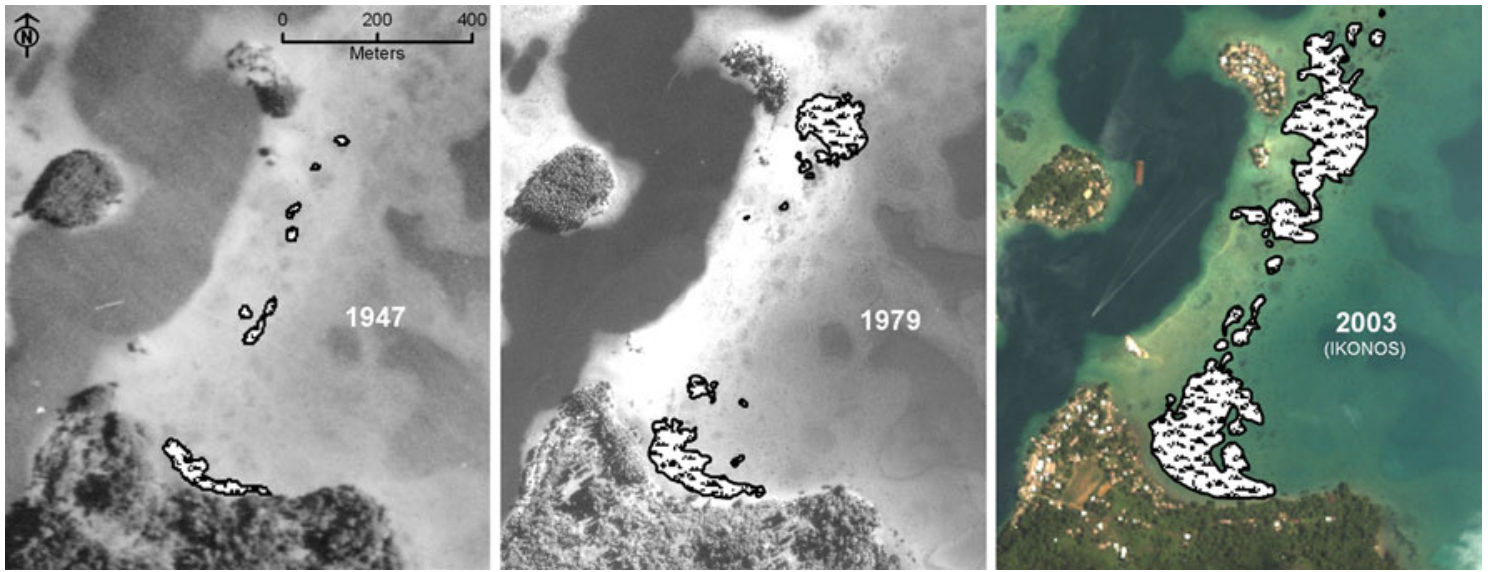

Fig. 4 Air photographs and satellite image with delineated areas indicating the size of seagrass meadows at Nusa Hope Village in 1947, 1979, and 2003 
using field-based surveys. Identification of seagrass meadows in the historical imagery was based on our longterm experience working in the region and comparisons with the recent imagery that we ground-truthed with field surveys. Once the seagrass meadows were digitized, we calculated their areas in hectares for each year that images were taken, and then we compared their sizes over time. Errors associated with GPS measurements, digitizing, and rectifying are estimated to be $\pm 5 \mathrm{~m}$ either side of the meadow edge.

\section{Results}

Seagrass and Indigenous Ecological Knowledge

The semi-structured and group interviews showed that indigenous ecological knowledge regarding seagrass ecology and human uses are intertwined with the myths and cultural history of Roviana people. A village elder explains:

Seagrass first grew many, many years ago near Rano Village on the island of Duke. That was the time of our ancestors and at that time Duke was not an island, it was a reef. It took a long time before the reef grew up from the sea and was dry. Every coral and reef died as the island went dry. When it became too dry the seagrass meadows died, but just before it died a spirit-man went and retrieved the seagrass spirit. The spirit-man said "Ok, seagrass you will aid the people, especially in their fishing". Today a man can increase his luck fishing by taking the center fiber of three seagrass leaves and twisting them together. This twisting calls the seagrass spirits and increases your luck when fishing. Once the strands are twisted it is like thin twine. Then, when you go fishing and you reach a place where you want to fish, you tie a knot in the seagrass twine and sing out as loud as you can "Seagrass of Kaovi! (Kuli pa Kaovi!)" If you do this, you will catch fish. You are calling the seagrass spirits from Kaovi Island, which is the home of the seagrass spirit (Interview, July 30, 2008).

This creation story illustrates one of several spiritual uses of seagrass. Tying seagrass twine knots is also thought to be useful as an aphrodisiac spell to attract a member of the opposite sex (vinaroro) as well as to ensure that a newborn child will be gifted in some special craft or art (matazonga). In each case, specific tying procedures and incantations are required in order to produce the desired effect. The seagrass used in these rituals is Enhalus acoroides, known as kuli gele in Roviana, which translates as "long seagrass" and describes the elongated strap-like leaves. Shorter seagrass species (primarily Thalassia hemprichii and Halophila ovalis) are also abundant in Roviana Lagoon and are called kuli ngongoto (literally "trimmed seagrass"). Kuli is the generic word for seagrass while kulikuliana refers to seagrass beds or meadows.

Roviana villagers use $E$. acoroides not only for ritual purposes, but also for practical activities. In some cases villagers used the dried leaves as stuffing for pillows. While older informants indicated that before the introduction of monofilament fishing line the fibers of $E$. acoroides leaves had many uses such as assembling fishing lures. In other Pacific Island societies fishers used the fibers to construct fishing nets that would last many years (Falanruw 1992). Today in Roviana, it continues to be used for shell necklaces and also to catch banded mantis shrimp (Lysiosquillina maculata) known as hahaka.

In addition to these spiritual and practical uses, Roviana fishers have rich ecological knowledge of seagrass. They explained how seagrass grows best in substrates composed of mixed sand and silt. This bottom type is thought to be softer and more "fertile" (masuru) for the seagrass, allowing its roots to spread and grow. If the substrate has too much gravel, wave action moves the gravel and breaks up the roots, while substrates that are too solid do not allow the seagrass roots to take hold. Of the two locally recognized seagrasses, kuli ngongoto (primarily Thalassia hemprichii and Halophila ovalis) is understood to prefer substrates with more sand than silt, while E. acoroides prefers a softer, silty habitat. Informants also commented that seagrass only grows in the shallower water, although Thalassia hemprichii and Halophila ovalis can grow in deeper water than E. acoroides. Favorable water movement caused by currents is also known to be a necessary and important component for healthy seagrass meadows. The currents bring floating detritus (or detritus in the upper layer of the water column) (pogoga) from inside the lagoon and then flush the area with fresh seawater. Areas that undergo this cycle of dirty and fresh water are thought to be the most suitable for seagrass meadows. Some informants mentioned that E. acoroides seagrass prefers cooler, slightly brackish water. Thus, proximity to sources of fresh water like rivers is thought to be one of the factors that cause seagrass to grow in some places and not in others. Seagrass is also known to have seeds that float and then eventually fall to the sea bottom and spread seagrass.

The semi-structured and group interviews also revealed how seagrass meadows provide many benefits to Roviana villagers. Most directly, seagrass is sometimes used as a food source. Several informants noted that the roots of E. acoroides were eaten raw, but this is a rare practice today. The meadows are also noted for calming wind waves (i.e., wave attenuation), which makes paddling easier through sections of the lagoon where it exists. But by far the most important 
Table 1 Villagers' descriptions of the major resident species inside or along the edges of seagrass meadows around Nusa Hope village

\begin{tabular}{ll}
\hline English name & Latin binomial \\
\hline Barred garfish & Hemiramphus far \\
Blue-tail mullet & Valamugil seheli \\
Checkered seaperch & Lutjanus decussatus (?) \\
Cockles & Acrosterigma spp. \\
Dugong & Dugong dugon \\
Goldlined rabbitfish & Siganus lineatus \\
Great barracuda & Sphyraena barracuda \\
Green turtle & Chelonia mydas \\
Hawksbill turtle & Eretmochelys imbricate \\
Ark shells & Anadara antiquata/trapezia \\
Squid & Idiosepius spp. \\
Spinefoot rabbitfish & Siganus spinus \\
Titan triggerfish & Balistoides viridescens \\
Trevally & Carangidae \\
Venus shells & Gafrarium tumidum \\
Yellow-margin triggerfish & Pseudobalistes flavimarginatus \\
\hline
\end{tabular}

benefit of seagrass, as indicated through interview ranking exercises, is the habitat it provides for marine animals that villagers depend on for daily subsistence (Table 1).

Although seagrass meadows provide many benefits, they also pose some problems and annoyances for Roviana villagers. Most frequently, fishing with a line and hook can be problematic in seagrass since hooks easily snag on the leaves. Swimming or diving in seagrass is also avoided because the leaves have sharp edges that can cut skin. The meadows also tend to contain detritus that causes skin irritations. During the wind season, known as peza (or westerly winds), seagrass can annoy villagers when it accumulates along the shoreline and creates a mess. Frequently during this season, seagrass is uprooted and blown to the village shoreline, from where it then has to be removed. Seagrass is also a nuisance for outboard motors. The long leaves of $E$. acoroides easily tangle a propeller and can ruin an engine if not promptly removed.

\section{Perceptions of Environmental Change}

In Baraulu, $68 \%$ of the 35 respondents stated that the seagrass meadow near their village had not changed in size over their lifetimes. The remaining $32 \%$ of Baraulu respondents stated that the spatial extent of the seagrass meadow near their village had expanded substantially. Respondents' answers did not differ significantly by gender $\chi^{2}(1, N=35)=2.08$, $p=.15$ or by age $\chi^{2}(2, N=35)=1.59, p=.45$ when grouped into young (age $<45$ ), middle $(46-65)$, and old ( $>65$ ) age groups. In Nusa Hope, $100 \%$ of the 40 respondents stated that the vegetation cover of their seagrass meadow had
Table 2 Explanations for expanding seagrass meadows around Nusa Hope village

\begin{tabular}{lc}
\hline Explanation & Respondents \\
\hline Sand bottom has become more silty & $13(33 \%)$ \\
Increase in dirty water from estuary & $8(21 \%)$ \\
Sand bottom has become softer & $7(18 \%)$ \\
Increase in the amount of dirty seawater & $5(13 \%)$ \\
Logging on the mainland has caused more & $5(13 \%)$ \\
silt to enter the lagoon & $4(10 \%)$ \\
Currents have increased in strength & $3(8 \%)$ \\
Climate has changed & $3(8 \%)$ \\
Sea level has risen (higher low and high tides) & $3(8 \%)$ \\
I don't know & $1(3 \%)$ \\
Increase in the number of sea urchins & $1(3 \%)$ \\
Sand has changed color from white to brown & $1(3 \%)$ \\
Increase in the amount of green algae & $1(3 \%)$ \\
Seawater is cooler than before &
\end{tabular}

expanded. The respondents from Nusa Hope identified a variety of factors to explain the dramatic size increase of the seagrass meadow (Table 2). These included sea-level rise, changes to the sand bottom substrate, increase in dirty sea water, increase in dirty water from the rivers, increase in the number of sea urchins, changes in the lagoon currents, and climate changes. Fifty percent of respondents $(n=20)$ believed that changes in the substrate were causing the seagrass meadows to expand.

Members participating in the Baraulu group interview concluded unanimously that the seagrass meadow near their village had not grown, while Nusa Hope group interview participants agreed that their seagrass meadow had expanded substantially. During the group interview in Nusa Hope a consensus emerged that seagrass (both $E$. acoroides and the kuli ngongoto species Thalassia hemprichii and Halophila ovalis) meadow growth was attributed to two casual factors: seal level rise and an increase in cool, silty river water flowing into the lagoon from the mainland. Evidence of gradual sea-level rise was obvious to the villagers. They stated that several decades ago during low tide they walked on exposed reef between the various small islands of Nusa Hope village. Today, these areas remain underwater even during low tides. This change in sea level occurred prior to a powerful 8.1 earthquake that stuck in April 2007 just south of New Georgia Island (Taylor and others 2008). According to the villagers, sea level rose slightly during the earthquake, indicating that the landmass of New Georgia subsided during the seismic event. Higher sea level was thought to protect seagrass meadows from the sun during low tides. Villagers commented that during masa rane (diurnal low-tide season) seagrass meadows of $E$. acoroides contract as the sun "burns" the exposed vegetation. With sea-level rise, 
seagrass meadows located in areas with suitable substrate characteristics no longer contracted and were able to expand into newly inundated habitats.

Villagers also noted that over their lifetimes an increasing volume of river water has been entering the lagoon. This increase of river water is thought to effect seagrass in two ways. First, it cools the seawater and makes it less salty, two characteristics that encourage seagrass growth. The best seagrass growth is thought to occur when the currents pass cool and then warm water through the meadow. More river water has meant cooler temperatures during the ebbing tide and hence increased growth of the seagrass. River water also adds more silt and dirt to the lagoon. Pogoga (dirty water in the upper part of the water column) is thought to be important for seagrass growth. Villagers explained that two changes were causing the increased flow of river water. The first was increased rainfall. There was not complete consensus on this change among informants, but some argued that annual rainfall levels had increased over their lifetimes. The second factor was extractive logging activity on the mainland. The group was unanimous that road cuts and other forest disturbances caused by timber extraction activities in the watershed behind Nusa Hope was one factor influencing the growth of seagrass meadows around Nusa Hope. No logging activities, according to our informants, have occurred in the forest near Baraulu until very recently and it was for this reason, they argued, that the seagrass meadows around Baraulu had not expanded.

\section{Multi-temporal Spatial Analysis of Seagrass Distribution}

Between 1947 and 2003, the vegetation cover of the Baraulu seagrass meadow decreased 0.09 ha (from $0.73 \pm$ 0.25 ha to $0.64 \pm 0.15$ ha) or $7.3 \%$ (Fig. 5), but the measured change did not exceed the estimated $\pm 5 \mathrm{~m}$ mapping,
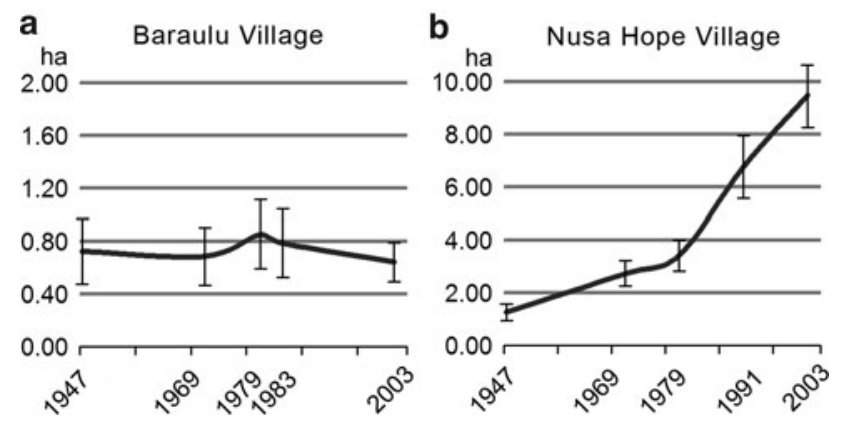

Fig. 5 Changes in seagrass meadow size (ha) near a Baraulu Village based on analyses of aerial photographs from 1947, 1969, 1979, 1983, and a 2003 IKONOS image and b Nusa Hope Village based on analyses of aerial photographs from 1947, 1969, 1979, 1991, and a 2003 IKONOS image interpretation, and processing error. Likewise, the Baraulu seagrass showed measurable contractions and expansions over each study period, but the changes were within the margin of error. From 1947 to 1969 the meadow decreased $5.6 \%$ from $0.72 \pm 0.25$ ha to $0.69 \pm 0.22 \mathrm{ha}$, then increased $24.4 \%$ to $0.85 \pm 0.26$ ha in 1979 , decreased $7.8 \%$ to $0.79 \pm 0.26$ in 1983 , and decreased $18.3 \%$ to $0.64 \pm 0.15$ ha in 2003. In contrast, the vegetation cover of the Nusa Hope seagrass meadow showed a dramatic increased in size over the entire 56-year period, expanding 8.23 ha or $651.5 \%$ from $1.26 \pm 0.31$ ha to $9.49 \pm 1.22$ ha. The data showed a clear trend of expanding vegetation coverage with consistent increases over all the measured time periods. Between 1947 and 1969 the vegetation cover increased from $1.26 \pm 0.31$ ha to $2.73 \pm 0.48$ ha, then to $3.42 \pm 0.59$ ha in $1979,6.76 \pm 1.19$ in 1991 , and $9.49 \pm$ 1.22 ha in 2003.

\section{Discussion}

\section{Distribution of Knowledge About Ecological Change}

Results suggest that fishers in Roviana Lagoon monitor ecological change around their villages successfully. This knowledge, however, is not always wide-ranging and can be unevenly distributed within communities. While a majority of Baraulu respondents identified ecological trends correctly over one-third of respondents contradicted the remote sensing analysis and stated that the seagrass meadow near their village had expanded. These results suggest that livelihood dependencies and proximity to resources do not necessarily confer an all-embracing ability to monitor environmental conditions and provide further evidence that even in small, cultural homogenous communities levels of indigenous ecological knowledge varies (Atran and Medin 2008).

In the case of the Nusa Hope seagrass meadow, the remote sensing analysis showed nearly a sevenfold increase in its size. Nusa Hope respondents were unanimous in identifying this change, but local knowledge about the drivers of change was also distributed unevenly. This was evident in the respondent's descriptions about the causes of seagrass growth. Some villagers simply did not know why the seagrass had grown; others provided simplistic, one-dimensional answers such as "the sand bottom has become softer", and others elaborated sophisticated multi-casual explanations.

The group interviews with local experts yielded complex explanations for the seagrass growth. This may be attributable to the interviewing technique. Group interviews know also as focus groups have been shown to produce insights into complex behaviors and knowledge because of the "group effect" (Morgan 1993; Carey and 
Smith 1994). This is the synergy that occurs during group interviews where participants query, cross-examine, and explain their views to each other. We observed this effect during the group interviews in Roviana. The interviews were not sedate conversations but rather vigorous discussions with frequent debates. For example, local experts in both villages were unanimous that seagrasses (all species) grow best in substrates composed of mixed sand and silt, but there was significant debate concerning whether silt actually mixes into the sand or if it remains near the surface.

Group interviews also have at least two inherent weaknesses. First participants must self-disclose when expressing their opinions and views, and second socio-political concerns and vested interests inevitably inform respondents' interactions and opinions (Morgan 1996). Logging, for example, is a contentious topic that divides Roviana communities and generates frequent land tenure disputes. Participants in the group interviews about this topic could have felt political pressure to withhold their opinions. Moreover, interpretations about the effects of logging on the lagoon ecosystem that emerged during the group interviews may have been political statements meant to influence other community members.

\section{Local Knowledge and Scientific Knowledge}

Local knowledge about seagrass ecology and its ecological services was quite consistent with scientific descriptions. Local experts knew tropical seagrass tends to grow best in substrates of mixed sand and silt, that it produces seeds to reproduce, that water movement is necessary for healthy growth, that strong wave action can destroy the seagrass roots and hinder growth, and that seagrass needs nutrients from detritus and sediment to grow (Larkum and others 2006). We also confirmed the local observations that $E$. acoroides tends to grow in shallower water than kuli ngongoto species such as Thalassia hemprichii and Halophila ovalis (Coles and Long 1999).

Roviana observations about the ecological services provided by seagrass meadows were equally notable. The scientific literature indicates that seagrass meadows provide sanctuary for a host of marine species, are food for certain herbivore species such as sea turtles, and that the meadows help attenuate wave energy (Larkum and others 2006). Scientific descriptions also confirmed that some species found in the Solomons such as E. acoroides prefer silty substrates with freshwater influence (Waycott and others 2004; Collier and Waycott 2009).

Local explanations that Nusa Hope seagrass meadows have expanded due to extractive logging activities on the mainland are also similar to scientific accounts that have documented increases in tropical seagrass biomass. Even though declining seagrass biomass and growth is the global trend (Orth and others 2006; Duarte and Gattuso 2008), small scale increases have been identified, particularly in tropical regions (Short and others 1985; Powell and others 1989; Short and others 1990; Powell and others 1991; Udy and others 1999; Campbell and others 2002). Like most marine primary producers, seagrass is limited by the availability of nitrogen and other nutrients in the water column. Under certain conditions, increased nutrient load has been shown to stimulate seagrass growth. Around Green Island reef, on Australia's Great Barrier Reef, for example, a documented increase in biomass and distribution of tropical seagrass over the last 50 years was attributed to local and regional anthropogenic sources that have increased the availability of nutrients (Udy and others 1999). A similar level of nutrient increase may be occurring in the waters around Nusa Hope. It is conceivable that the sporadic pulses of turbidity caused by extractive logging activities on mainland New Georgia have increased the nutrient load and suspended sediment enough to encourage seagrass growth, but not to levels sufficient to deprive the plants of light and cause die off (Longstaff and Dennison 1999).

Roviana villagers may also be correct about the effect of rising sea level on seagrass growth. Under the right conditions, rising sea level may facilitate the shoreward migration of seagrass (Orth and others 2006, p. 990). This process is not thoroughly documented because most regions of the world are experiencing increased anthropogenic pressure on the coastal zone that is destroying seagrass habitat faster than it could spread into newly inundated areas.

Due to gaps in the marine science literature, some of the information provided by Roviana informants could not be cross-checked. In the Solomons, only one country-wide, rapid-assessment survey has been carried out to assess seagrass habitats and identify species (McKenzie and others 2006). Also, it is important to note that during the group interviews, interviewees were not comfortable reducing their analyses of changing seagrass size to any single ecological factor. Reaching a group "consensus" about the causes driving seagrass growth was contentious. Although everyone agreed that sea-level rise and increased sediment were the main causes, the local experts frequently commented that other factors could be involved.

\section{Adaptive Management}

This study illustrates how some Roviana villagers monitor long-term ecological change around their communities and shows that their understandings about the drivers of change are similar to scientific explanations. Detecting change and understanding ecological feedbacks are crucial aspects of 
indigenous knowledge and are foundational to adaptive management frameworks. Without change-detection abilities, resource users have no way of knowing how to respond to environmental changes.

The ability to monitor change, however, does not guarantee the protection of biodiversity or prevent resource degradation. There must also be an intuitional setting in which observations of change can be interpreted and then acted upon. In Roviana Lagoon, like in some other Pacific societies, customary systems of marine tenure and traditional management practices can provide this intuitional setting. Even though customary governance systems may not be designed for conservation in a Western scientific sense, in some cases it leads to sustainable resource stewardship (Cinner and others 2005b; Aswani and Sabetian 2009).

Customary governance and indigenous knowledge have been central in the design, implementation, and monitoring of a community-based management initiative that we helped organize and administer in Roviana Lagoon (Aswani and others 2004; Aswani and others 2007). The overarching aim of the management initiative has been to develop hybrid methods to integrate ecological knowledge with scientific approaches such as underwater visual surveys for designing marine protected areas (MPAs). Beginning in 1999, the program has established marine protected areas, improved the basic infrastructure of the region, and conducted environmental awareness programs. With varying degrees of success, 30 MPAs are now operating around New Georgia, most of which have been set up as permanent "no-take" zones with village-based Resource Management Committees (RMCs) administering and patrolling them. Roviana Lagoon has nine MPAs, three of which are under the control of Baraulu and Nusa Hope villages.

An important feature of the customary governance system that forms the core of the conservation program is its capacity to adapt to changing environmental conditions. Several examples from the Baraulu and Nusa Hope MPAs illustrate this point. On several occasions the Baraulu and Nusa Hope RMCs have altered MPA management strategies based on new or initially overlooked information about the social-ecological system. For instance, in 2005, the Nusa Hope RMC decided to expand the southwest corner of their MPA to include a spawning aggregation of various grouper species (e.g., Epinephelus polyphekadion) that had not been included in the original boundary. This spawning aggregation was well known to the villagers prior to the establishment of the MPA, but many villagers were initially skeptical about closing such an important and conveniently located fishing ground. It was not until the RMC began to notice a spill-over effect from the MPA that they became convinced that closing this spawning aggregation would be beneficial (Aswani and others 2007). In this case, the new information was the increase in availability of fish in areas adjacent to the MPAs that led to an adaptation of the management system.

In a second example, the Baraulu RMC altered their MPA management strategy when villagers noticed (with the assistance of one of our team members) that several species of macro-algae (Caulerpa spp.) known as ime had begun to overgrow and kill some of the porites corals inside the MPA. The expansion of ime was in fact an unintended outcome of the MPA closure. Prior to the closure Roviana villagers frequently harvest several species of ime for food, a subsistence strategy that appears to have limited the growth of ime and prevented it from smothering the coral. When the RMCs became aware of the ime overgrowth they decided to allow women and girls to harvest ime within the boundaries of the MPA with the intention of keeping its growth in check.

These two examples illustrate how the RMCs have detected changes in ecological processes and responded with specific resource management decisions. In the case of the expanding seagrass meadows around Nusa Hope, the RMC recognizes that changes are occurring but have not instituted specific resource management policies focused on the seagrass meadows. When we inquired about the lack of response, villagers were ambivalent. One fisher summed up these feelings when he stated: "It's alright. It [seagrass] doesn't disturb us too much."

The villagers' ambivalence about the expanding seagrass meadows suggests that when faced with ecological change Roviana resource management practitioners have a certain degree of flexibility and openness, characteristics that are hallmarks of adaptive management systems. Berkes and others (1998, p. 21), for example, note that "successful knowledge and resource management systems will allow disturbances to enter on a scale which does not disrupt the structure and functional performance of the ecosystem and the services it provides". It stands to reason that the expanding Nusa Hope seagrass meadows represent this sort of disturbance. Seagrass growth, as interpreted by villagers, has not impaired (and might be enhancing) the ecological services provided to the community, and hence the RMC has not taken specific measures to respond to the changes.

A similar idea may explain why the RMCs in Roviana Lagoon have not tried to block extractive logging operations on the mainland. Interview results indicate that some community members perceive and understand the impacts of logging on lagoon ecology, but from their perspective the logging activities (selective logging) have not disrupted the marine ecosystem enough to hinder its ability to provide important ecological services. Since they think that the goods and services provided by the lagoon are not 
undermined, villagers have not responded to the change and the RMCs have not implemented new management practices.

However, the perceptions of the RMCs regarding seagrasses and logging might be flawed. It may be the case that socio-economic changes are masking ecological degradation of the lagoon. Logging activities, for example, inject more cash into the communities through royalties. This infusion of resources enables at least some villagers to purchase food and become less reliant on marine resources. With alternative means of acquiring food, local Roviana fishers may be less perceptive of decline in ecological services provided by changing seagrass meadows. Access to new technologies may have had a similar effect. Improvements in fishing tackle, nets, or other fishing gear, as well as recently introduced underwater torches and snorkeling gear, might conceal declining fish stocks. These socio-economic and technological changes may be distorting perceptions of ecological feedbacks and be causing the loss of ecological knowledge. This loss is also compounded by generational "shifting baselines" (Pauly 1995) about environmental characteristics and productivity. Over time, traditional governance of environmental resources in Roviana Lagoon has been steadily undermined by these trends.

\section{Conclusion}

Much recent interest in indigenous knowledge is motivated by the idea that some traditional societies practice sustainable resource use and that these "ancient cultural practices are more than anthropological curiosities; they are part of humanity's wealth of adaptations that can serve the contemporary world as well" (Holling and others 1998, p. 351). Although indigenous practices may serve as an inspiration they also can teach us many lessons. Many studies document how some traditional societies damage local ecosystems and undermine biodiversity (Redman 1999; Hames 2007; Erlandson and Rick 2009).

Those traditional management systems that have successfully managed resource use over the long term are built upon an important feature-the ability of local resource users to detect, interpret, and respond to long- and shortterm ecological change. This paper documents the abilities of Roviana fisherfolk to discern changes in seagrass meadows. Results show that although a majority of respondents in both villages were able to detect ecological change, but not all community members were equally knowledgeable about the scale, direction, and potential causes of change occurring to the seagrass meadows around their communities. Moreover, when changes were minimal or non-existent over one-third of the respondents incorrectly detected changes.

More research is needed to gain a clearer understanding of the change-detection abilities of local resource users and their interpretations of the dynamics driving ecosystem change. In-depth analyses of how factors such as livelihood, educational levels, dependency on resources, or socio-economic conditions influence change detection abilities and local ecological knowledge are critically important for revealing how societies respond and adapt to changing social-ecological conditions. Moreover, the principles underlying resource monitoring and the mechanisms by which they shape effective management are crucial for identifying strategies of adaptive governance that are socially acceptable and ecologically sustainable over the long term. Considering the planetary dimensions and ever-increasing pace of ecosystem degradation, the urgency for greater clarity about these issues cannot be understated.

Acknowledgements Many thanks to the people of Roviana and Vonavona Lagoons for supporting our research and to the Provincial and National Governments of the Solomon Islands for permission to carry out our program. Thanks also to Jackson Vaikota, the Surveyor General of the Ministry of Lands, Housing, and Survey, for helping us to acquire historical aerial photographs of Western Province, Solomon Islands. We also thank Joelle Prange for her insightful comments on a previous draft of this paper. We want to thank the David and Lucile Packard Foundation (2001-17407 and 2005-447628-58080), Conservation International-GCF (447628-59102), the National Science Foundation (NSF-CAREER-BCS-0238539), and San Diego State University for their generous support.

Open Access This article is distributed under the terms of the Creative Commons Attribution Noncommercial License which permits any noncommercial use, distribution, and reproduction in any medium, provided the original author(s) and source are credited.

\section{References}

Aswani S (2005) Customary sea tenure in Oceania as a case of rightsbased fishery management: does it work? Reviews in Fish Biology and Fisheries 15:285-307

Aswani S, Lauer M (2006) Incorporating fishers' local knowledge and behavior into geographical information systems (GIS) for designing marine protected areas in Oceania. Human Organization 65:80-101

Aswani S, Sabetian A (2009) Implications of urbanization for artisanal parrotfish fisheries in the western Solomon Islands. Conserv Biol, published online before print, 24 Nov 2009. doi: 10.1111/j.1523-1739.2009.01377

Aswani S, Vaccaro I (2008) Lagoon ecology and social strategies: habitat diversity and ethnobiology. Human Ecology 36:325-341

Aswani S, Lauer M, Weiant P, Geelen L, Herman S (2004) The Roviana and Vonavona marine resource management project, final report, 2000-2004. Department of Anthropology, University of California, Santa Barbara 
Aswani S, Albert S, Sabetian A, Furusawa T (2007) Customary management as precautionary and adaptive principles for protecting coral reefs in Oceania. Coral Reefs 26:1009-1021

Atran S, Medin DL (2008) The native mind and the cultural construction of nature. MIT Press, Cambridge, MA

Begossi A (1998) Resilience and neo-traditional populations: the caiçaras (Atlantic Forest) and caboclos (Amazon, Brazil). In: Berkes F, Folke C, Colding J (eds) Linking social and ecological systems: management practices and social mechanisms for building resilience. Cambridge University Press, Cambridge, pp 129-157

Berkes F (1998) Indigenous knowledge and resource management systems in the Canadian subarctic. In: Berkes F, Folke C, Colding $\mathbf{J}$ (eds) Linking social and ecological systems: management practices and social mechanisms for building resilience. Cambridge University Press, Cambridge, pp 98-128

Berkes F, Folke C, Colding J (1998) Linking social and ecological systems: management practices and social mechanisms for building resilience. Cambridge University Press, Cambridge

Berkes F, Colding J, Folke C (2000) Rediscovery of traditional ecological knowledge as adaptive management. Ecological Applications 10:1251-1262

Berkes F, Colding J, Folke C (2003) Navigating social-ecological systems: building resilience for complexity and change. Cambridge University Press, Cambridge

Berner J, Symon C, Arris L, Heal OW (2005) Arctic climate impact assessment. Cambridge University Press, New York, NY

Campbell SJ, Roder CA, McKenzie LJ, Lee Long WJ (2002) Seagrass resources in the Whitsunday region 1999 and 2000. DPI Information Series QI02043

Carey MA, Smith MW (1994) Capturing the group effect in focus groups: a special concern in analysis. Qualitative Health Research 4:123-127

Cinner J, Marnane MJ, McClanahan TR, Almany GR (2005a) Periodic closures as adaptive coral reef management in the IndoPacific. Ecology and Society 11:31

Cinner JE, Maarane MJ, McClanahan TR (2005b) Conservation and community benefits from traditional coral reef management at Ahus Island, Papua New Guinea. Conservation Biology 19:1714-1723

Coles R, Long WL (1999) Seagrasses. In: Eldredge LG, Maragos JE, Holthus PF, Takeuchi HF (eds) Marine and coastal biodiversity in the tropical island Pacific region: population, development and conservation priorities. East-West Center, Honolulu, HI, pp 21-46

Collier C, Waycott M (2009) Drivers of change to seagrass distributions and communities on the Great Barrier Reef. Report to the Marine and Tropical Sciences Research Facility, Reef and Rainforest Research Centre Limited, Cairns

Crate SA (2008) Gone the bull of winter? Grappling with the cultural implications of and anthropology's role(s) in global climate change. Current Anthropology 49:569-595

Dietz T, Ostrom E, Stern PC (2003) The struggle to govern the commons. Science 302:1907-1912

Drew J (2005) Use of traditional ecological knowledge in marine conservation. Conservation Biology 19:1286-1293

Duarte CM (2002) The future of seagrass meadows. Environmental Conservation 29:192-206

Duarte C, Gattuso J-P (2008) Seagrass meadows. In: Cleveland CJ (ed) Encyclopedia of earth, environmental information coalition. National Council for Science and the Environment, Washington, DC

Duarte CM, Dennison WC, Orth RJW, Carruthers TJB (2008) The charisma of coastal ecosystems: addressing the imbalance. Estuaries and Coasts 31:233-238
Erlandson JM, Rick TC (2009) Archaeology, marine ecology, and human impacts on marine environments. In: Rick TC, Erlandson J (eds) Human impacts on ancient marine ecosystems: a global perspective. University of California Press, Berkeley, CA, pp 1-19

Falanruw MC (1992) Seagrass nets. Atoll Research Bulletin 364:1-12

Folke C, Hahn T, Olsson P, Norberg J (2005) Adaptive governance of social-ecological systems. Annual Review of Environment and Resources 30:441-473

Green EP, Short FT (2003) World atlas of seagrasses. University of California Press, Berkeley, CA

Green A, Lokani P, Atu W, Ramohia P, Thomas P, Almany J (2006) Solomon Islands marine assessment: Technical report of survey conducted May 13 to June 17, 2004. TNC Pacific Island Countries. TNC Pacific Islands Country Report No. 1/06

Gunderson LH, Pritchard L (2002) Resilience and the behavior of large scale systems. Island Press, Washington, DC

Hames R (2007) The ecologically noble savage debate. Annual Review of Anthropology 36:177-190

Holling CS (1978) Adaptive environmental assessment and management. Wiley, New York

Holling CS, Berkes F, Folke C (1998) Science, sustainability and resource management. In: Berkes F, Folke C, Colding J (eds) Linking social and ecological systems: management practices and social mechanisms for building resilience. Cambridge University Press, Cambridge, pp 342-362

Hughes TP, Bellwood DR, Folke C, Steneck RS, Wilson J (2005) New paradigms for supporting the resilience of marine ecosystems. Trends in Ecology \& Evolution 20:380-386

Huntington HP (2000) Using traditional ecological knowledge in science: methods and applications. Ecological Applications 10:1270-1274

IPCC (2007) Summary for policymakers. In: Parry ML, Canziani OF, Palutikof JP, van der Linden PJ, Hanson CE (eds) Climate change 2007: impacts, adaptation and vulnerability. Contribution of working group II to the fourth assessment report of the intergovernmental panel on climate change. Cambridge University Press, Cambridge, UK, pp 7-22

Jackson JBC, Kirby MX, Berger WH, Bjorndal KA, Botsford LW, Bourque BJ, Bradbury RH, Cooke R, Erlandson J, Estes JA, Hughes TP, Kidwell S, Lange CB, Lenihan HS, Pandolfi JM, Peterson CH, Steneck RS, Tegner MJ, Warner RR (2001) Historical overfishing and the recent collapse of coastal ecosystems. Science 293:629-638

Johannes RE (1978) Traditional marine conservation methods in Oceania and their demise. Annual Review of Ecology and Systematics 9:349-364

Krech S (1999) The ecological Indian: myth and history, 1st edn. W.W. Norton \& Company, New York

Larkum AWD, Orth RJ, Duarte CM (2006) Seagrasses: biology, ecology and conservation. Springer, Dordrecht, The Netherlands

Lauer M, Aswani S (2008) Integrating indigenous ecological knowledge and multi-spectral image classification for marine habitat mapping in Oceania. Ocean and Coastal Management 51:495-504

Lauer M, Aswani S (2009) Indigenous ecological knowledge as situated practices: understanding fishers' knowledge in the western Solomon Islands. American Anthropologist 111:317-329

Liu JG, Dietz T, Carpenter SR, Alberti M, Folke C, Moran E, Pell AN, Deadman P, Kratz T, Lubchenco J, Ostrom E, Ouyang Z, Provencher W, Redman CL, Schneider SH, Taylor WW (2007) Complexity of coupled human and natural systems. Science 317:1513-1516

Longstaff BJ, Dennison WC (1999) Seagrass survival during pulsed turbidity events: the effects of light deprivation on the seagrasses 
Halodule pinifolia and Halophila ovalis. Aquatic Botany 65:105-121

McClanahan TR, Marnane MJ, Cinner JE, Kiene WE (2006) A comparison of marine protected areas and alternative approaches to coral reef management. Current Biology 16:1408-1413

McKenzie L, Campbell S, Lasi F (2006) Seagrasses and mangroves. In: Green A, Lokani P, Atu W, Ramohia P, Thomas P, Almany J (eds) Solomon Islands marine assessment: technical report of survey conducted May 13 to June 17, 2004. TNC Pacific Islands Country Report No. 1/06, TNC Pacific Island Countries

Morgan DL (1993) Successful focus groups: advancing the state of the art. Sage Publications, Newbury Park, CA

Morgan DL (1996) Focus groups. Annual Review of Sociology 22: $129-152$

Murdoch J (1994) Sustainable knowledge. Geoforum 25:115-132

Niamer-Fuller M (1998) The resilience of pastoral herding in Sahelian Africa. In: Berkes F, Folke C, Colding J (eds) Linking social and ecological systems: management practices and social mechanisms for building resilience. Cambridge University Press, Cambridge, pp 250-284

Olsson P, Folke C, Berkes F (2004) Adaptive comanagement for building resilience in social-ecological systems. Environmental Management 34:75-90

Orth RJ, Carruthers TJB, Dennison WC, Duarte CM, Fourqurean JW, Heck KL, Hughes AR, Kendrick GA, Kenworthy WJ, Olyarnik S, Short FT, Waycott M, Williams SL (2006) A global crisis for seagrass ecosystems. BioScience 56:987-996

Pauly D (1995) Anecdotes and the shifting baseline syndrome of fisheries. Trends in Ecology \& Evolution 10:430

Pinkerton E (1989) Co-operative management of local fisheries: new directions for improved management and community development. University of British Columbia Press, Vancouver

Powell GVN, Kenworthy WJ, Fourqurean JW (1989) Experimental evidence for nutrient limitation of seagrass growth in a tropical estuary with restricted circulation. Bulletin of Marine Science 44:324-340

Powell G, Fourqurean J, Kenworthy W, Zieman J (1991) Bird colonies cause seagrass enrichment in a subtropical estuary: observational and experimental evidence. Estuarine, Coastal and Shelf Science 32:567-579

Redman CL (1999) Human impact on ancient environments. University of Arizona Press, Tucson

Short FT, Wyllei-Echeverria S (1996) Natural and human-induced disturbance of seagrasses. Environmental Conservation 23: $17-27$
Short F, Davis M, Gibson R, Zimmermann C (1985) Evidence for phosphorus limitation in carbonate sediments of the seagrass. Estuarine, Coastal and Shelf Science 20:419-430

Short T, Dennison WC, Capone DG (1990) Phosphorus-limited growth of the tropical seagrass Syringodium filiforme in carbonate sediments. Marine Ecology Progress Series 62:169-174

Short F, Carruthers T, Dennison W, Waycott M (2007) Global seagrass distribution and diversity: a bioregional model. Journal of Experimental Marine Biology and Ecology 350:3-20

Sillitoe P (1998) The development of indigenous knowledge: A new applied anthropology. Current Anthropology 39:223-252

Steffen WL (2004) Global change and the earth system: a planet under pressure. Springer, Berlin

Stoffle RW, Halmo DB, Wagner TW, Luczkovich JJ (1994) Reefs from space: satellite imagery, marine ecology, and ethnography in the Dominican Republic. Human Ecology 22:355-378

Taylor FW, Briggs RW, Frohlich C, Brown A, Hornbach M, Papabatu AK, Meltzner AJ, Billy D (2008) Rupture across arc segment and plate boundaries in the 1 April 2007 Solomons earthquake. Nature Geoscience 1:253-257

Udy JW, Dennison WC, Long WJL, McKenzie LJ (1999) Responses of seagrass to nutrients in the Great Barrier Reef, Australia. Marine Ecology Progress Series 185:257-271

Walter R, Sheppard P (2000) Nusa Roviana: the archaeology of a Melanesian chiefdom. Journal of Field Archaeology 27:295-318

Walters CJ (1986) Adaptive management of renewable resources. Macmillan, New York

Waycott M, McMahon K, Mellors J, Calladine A, Kleine D (2004) A guide to tropical seagrasses of the Indo-West Pacific. James Cook University, Townsville

Waycott M, Duarte CM, Carruthers TJB, Orth RJ, Dennison WC, Olyarnik S, Calladine A, Fourqurean JW, Heck KL, Hughes AR, Kendrick GA, Kenworthy WJ, Short FT, Williams SL (2009) Accelerating loss of seagrasses across the globe threatens coastal ecosystems. Proceedings of the National Academy of Sciences 106:12377-12381

Worm B, Hilborn R, Baum JK, Branch TA, Collie JS, Costello C, Fogarty MJ, Fulton EA, Hutchings JA, Jennings S, Jensen OP, Lotze HK, Mace PM, McClanahan TR, Minto C, Palumbi SR, Parma AM, Ricard D, Rosenberg AA, Watson R, Zeller D (2009) Rebuilding global fisheries. Science 325:578-585 